\title{
Assessment of Heavy Metals Contamination at Cape Town Landfill Sites
}

\author{
Adelaja O. Osibote and Ademola M. Rabiu
}

\begin{abstract}
Heavy metals (HM) contents of municipal solid waste (MSW) are of immense concern in their management and disposal system around the world. Landfilling (and in worse case dumping) remains the preferred disposal method for MSW in majority of Africa countries. Consequently, the HMs, also found in household, medical and industrial waste, ends up in landfills and dumpsites. Over time, if not properly managed, these metals present a contamination risk to the nearby soil, ground and surface water, as well as the biodiversity that depends on these resources; this may contaminate the food chain. This paper reported the spatial distribution of heavy metal concentrations in the topsoil from Cape Town landfill sites using the Inductively-Coupled Plasma Optical Emission Spectrometry (ICP-OES). The results show that the concentrations of the heavy metals found decreases with distance from the landfill sites except for $\mathrm{Cd}$ which have the concentration to be high close to the road. Recommendations on proper management and monitoring systems of the existing waste sites that will limit the exposure of the populations to these elements were made.
\end{abstract}

Index Terms-Municipal solid waste, heavy metals, leachate, cape town landfills.

\section{INTRODUCTION}

Heavy Metals (HM) well-known for their toxic effects on humans and the environments are found in industrial, construction, medical and even general household wastes. Some heavy metals like mercury, lead, and cadmium are added to certain consumer and industrial products such as batteries, switches, circuit boards, and certain pigments. Mercury was once widely used in pharmaceutical products, agricultural chemicals, dry cell batteries, and paints. Many of these uses have been phased out, although others continue, e.g. chlor-alkali production, switches and electrical apparatus, fluorescent light bulbs, and dental amalgam. These ongoing uses of mercury too are declining. In 2004, world mercury production was estimated to be 1260 metric tons per year, which was significantly less than the $2200 \mathrm{t} / \mathrm{y}$ average world mercury production from 1990 to 2000 [1]. Cadmium was at one time widely used in electroplating processes to coat iron and steel. In recent years, cadmium has been used increasingly for the production of rechargeable batteries, and this is now the dominant use of the metal. The frequently used option for many products containing heavy metals is

Manuscript received December 21, 2015; revised February 17, 2016.

A. O. Osibote is with the Department of Mathematics and Physics, Faculty of Applied Science, Cape Peninsula University of Technology, Cape Town, South Africa (e-mail: osibotea@cput.ac.za).

A. M. Rabiu is with the Department of Chemical Engineering, Faculty of Engineering, Cape Peninsula University of Technology, Cape Town, South Africa (e-mail: rabiua@cput.ac.za). disposed in a municipal solid waste or hazardous waste landfill or dumpsite [1]. Landfilling involves disposing of waste on land in a series of compacted layers and covering it up with soil and other material. In Cape Town, the major process being used at present for solid waste management is landfill disposal. About 1.6 million tons of waste was landfilled in the city's three landfill sites in 2010.

Electronic waste particularly computers parts contain small amount of toxic heavy metals. And also wastes from battery manufacturing, petrochemical, electroplating industries, etc. contain toxic heavy metals such as cadmium, chromium, lead, nickel, zinc, mercury, copper, arsenic. The presence of these toxic metals in landfilled wastes poses serious threats to the environment.

Landfilling of solid wastes releases greenhouse gases [2] and volatile organic compounds [3] along with leachable toxic heavy metals [4] to the surrounding environment [5].

HM contents of Municipal Solid Waste (MSW) which therefore ends up in landfills and dumpsites are of immense environmental and public health concern. Over time, and when not properly managed, these metals present a contamination risk to the nearby soil, ground and surface water [5]-[7], the biodiversity that depends on these resources as well as the microbial ecophysiological indicators [6] of the surrounding soils. The HM-rich leachate may percolate into soils underlying the disposal site [8], [9]. Soils are usually considered as a sink for trace/heavy metals, it also known that heavy metals are not biodegradable, they therefore are able to move towards a water column or accumulate in plants and consequently contaminate the food chain. There is therefore, the need to analyse the distribution of HMs content in soil samples from landfills in order to ascertain natural and artificial levels of HM in and around the sites.

Landfill disposal is still the major process being used because it is simple, practical and cheap. However, because of more rapid exhaustion of the landfill sites in use and because of the impacts it has on ecology, health and environment, people have become aware of the need to develop alternative waste disposal technologies. Landfilling in particular is increasingly being globally recognised as an unsustainable method for waste management.

The National Waste Management Strategy (NWMS), the White paper on Integrated Pollution and Waste Management for South Africa, and the National Environmental Management: Waste Act (NEMWA, No 58 of 2009) are the national policy and regulatory instruments governing municipal solid waste management. The current MSW management systems include waste collection and sorting for materials recovery followed by landfilling. The city operates 
three landfill sites and transfer stations; two materials recovery facilities and 25 public drop-off sites. Landfill sites are licensed in accordance with the requirements of the National Water Act, and the Department of Water Affairs and Forestry guidelines. Historic problems experienced with MSW disposal facilities in South Africa include poor and inadequate design and operation which impacts negatively on both the environment and quality of life. In South Africa, domestic waste is disposed of at approximately 1200 landfills out of which only 524 are permitted and hazardous waste on 77 disposal sites of which 41 are permitted (DEAT, 2006a). The fact that only about 40 per cent of waste disposal sites in South Africa are permitted makes control and enforcement of minimum requirements/standards difficult.

As yet, very few published work can be found regarding the contamination levels of heavy metals in and around South African landfill sites, and none for Cape Town's landfill sites. This study aims to establish the magnitude of waste-derived heavy metals contamination in the management and disposal of MSW in Cape Town, South Africa. Specific objective include detailed analyses and assessment of the HM load at some of the City of Cape Town landfill sites.

\section{EXPERIMENTAL METHOD}

\section{A. Description of the Landfill Sites}

The landfill sites in this study are Bellville Landfill site, Vissershok Landfill Site and Coastal Park Landfill Site located in Cape Town. The total areas covered by the landfill sites are $0.60 \mathrm{~km}^{2}, 1.17 \mathrm{~km}^{2}$ and $0.75 \mathrm{~km}^{2}$ respectively while ages of the landfill sites are equally important for the assessment heavy metals distribution. Two of the landfill sites are approaching the design capacity on or before year 2022.

\begin{tabular}{llllll}
\multicolumn{5}{c}{ TABLE I: LANDFILL SITES IN CITY OF CAPE TOWN } \\
\hline $\begin{array}{l}\text { Landfill } \\
\text { Site }\end{array}$ & Location & $\begin{array}{l}\text { Area } \\
\mathrm{m}^{2}\end{array}$ & $\begin{array}{l}\text { Height } \\
\mathrm{m}\end{array}$ & Age & End \\
\hline Bellville & SN EW & 600,000 & 35 & - & 2013 \\
$\begin{array}{l}\text { Coastal } \\
\text { Park }\end{array}$ & SN EW & 750,000 & $35-45$ & - & $2016-2022$ \\
Vissershok & SN EW & $1,170,000$ & 3065 & - & $>2022$
\end{tabular}

The area and the proximity map of the landfill sites is describe and shown in Fig. 1 a) \& b) respectively.

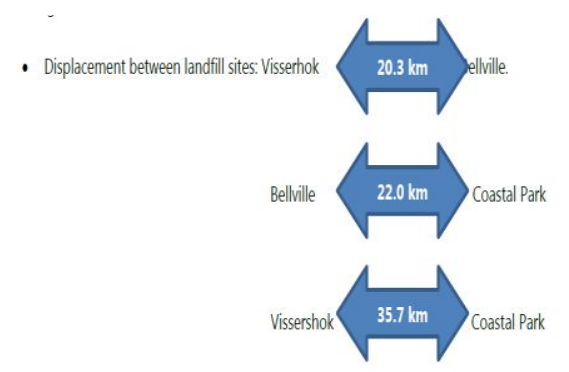

- Area between landfill sites $\quad: 205 \mathrm{~km}^{2}$

Fig. 1 a). The area between landfill sites.

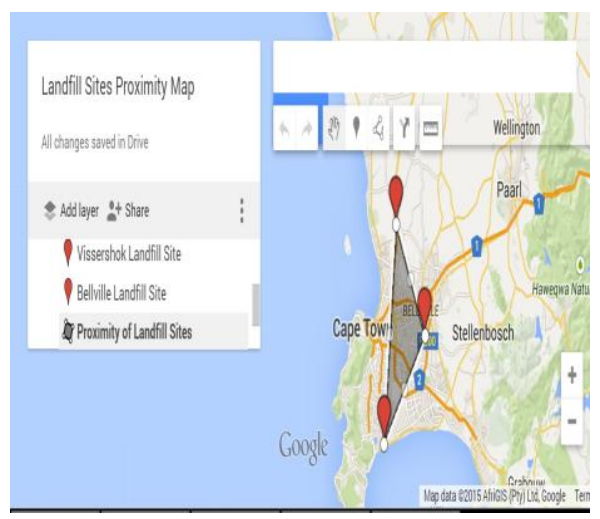

Fig. 1 b). The landfill sites proximity map.

\section{B. Site Mapping and Samples Collection}

A mapping of the landfill sites that reflect the topography was carried out, (Figure 2) which is about $50 \mathrm{~m}$ from the site. To ensure the integrity of the samples obtained, the surface soil samples were collected using a AMS regular step soil probe (5/8" threaded, nickel plated 33" plated step probe) at a sampling depth of 15 inch. A chrome-plated trowel was first used to remove surface debris before inserting the soil probe.

The collections were done between the months of February and March, that is, summer time in Cape Town. This period is described as hot and dry with no rain. The samples were transferred into sterilized 2-litres plastic containers and tightly sealed. The required amount was then transferred into soil sample bags.

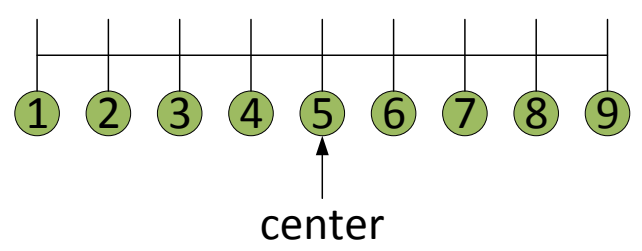

Fig. 2. Site grid layout (10m between nodes).

\section{Soil Samples Analysis}

The collected samples were grinded, homogenized, sieved to a specific size then dried for a period of time $(24 \mathrm{hr})$. The Inductively-Coupled Plasma Optical Emission Spectrometry (ICP-OES) technique was used to determine the samples metals content. The technique allows multi elemental analysis because of its wide dynamic range and sensitivity. The samples were digested using reagents with high purity deionized water and analyzed in triplicate. All reagents used were of analytical grade and from which standard solutions were prepared. Glassware was thoroughly washed with detergent and rinsed with distilled water. With regards to heavy metals, the major elements that were analyzed are As, $\mathrm{Sn}, \mathrm{Cd}, \mathrm{Al}, \mathrm{Cu}, \mathrm{Pb}, \mathrm{Zn}, \mathrm{Fe}$ and $\mathrm{Si}$.

\section{RESULTS AND DISCUSSIONS}

The concentrations of the different metals detected and measured in the samples are presented in Fig. 2 a)-d) as a function of the sampling points. The concentrations of $\mathrm{Al}$ and Fe give high range values of $15.17-32.35$ and $18.74-40.83$ $\mathrm{mg} / \mathrm{L}$ and means of 19.60 and $24.32 \mathrm{mg} / \mathrm{L}$ respectively, as compared to range values of $\mathrm{Pb}, \mathrm{Cu}$ and $\mathrm{Zn}(0.12-0.16,0.16$ 
$-0.24,0.64-1.16$ ) respectively. The values of $\mathrm{Pb}, \mathrm{Cu}$ and $\mathrm{Zn}$ are low as compared to some previous works which gives ranges of $44.09-291.29$ and $42.9-1833.5 \mathrm{mg} / \mathrm{kg}$ for $\mathrm{Pb}$ and $4.53-75.52$ and $11-186.6 \mathrm{mg} / \mathrm{kg}$ for $\mathrm{Cu}$ respectively [10], [11] From Figure 2, it can be concluded that the metals concentrations for $\mathrm{Al}, \mathrm{Fe}, \mathrm{Sn} ; \mathrm{Si}, \mathrm{Zn}$ in surface soil decreases with distance from the landfill site. The $\mathrm{Cu}, \mathrm{As}$ and $\mathrm{Pb}$ contents seems fairly constant. In the case of $\mathrm{Cd}$, the range value of $0.01-8.01 \mathrm{mg} / \mathrm{L}$ was measured, the level was found to be highest close to the road, and fairly constant at other points. The percolation mechanism for each of these metals is being investigated to account for this trend. The level of cadmium measured was found to be relatively low as compared to other metals detected. Living organisms even though requires some of the trace elements or HM for proper functioning of the organs and systems; also, with no clear boundary between the benefits and toxicity for these elements, the amount should be minimized because they are not metabolized by the body system thereby resulting in accumulation in some organs such as the liver.

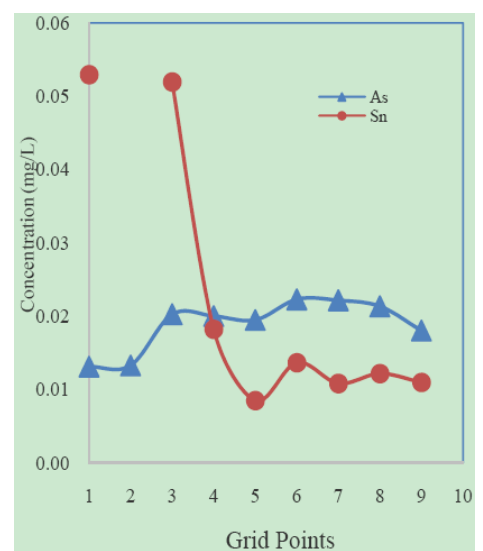

(a)

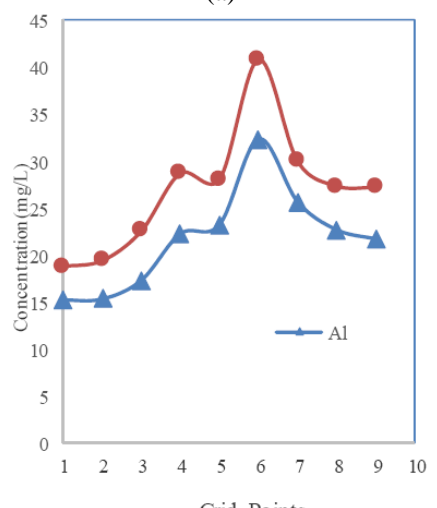

(b)

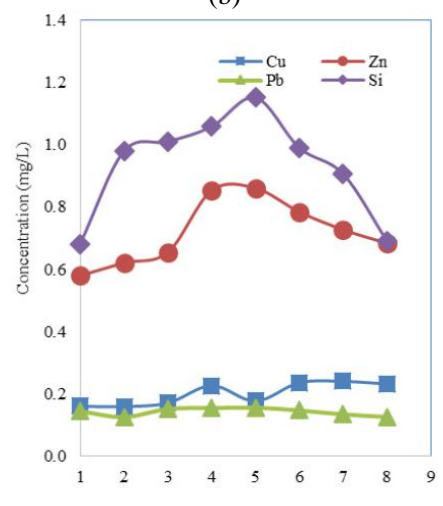

Grid Points

(c)

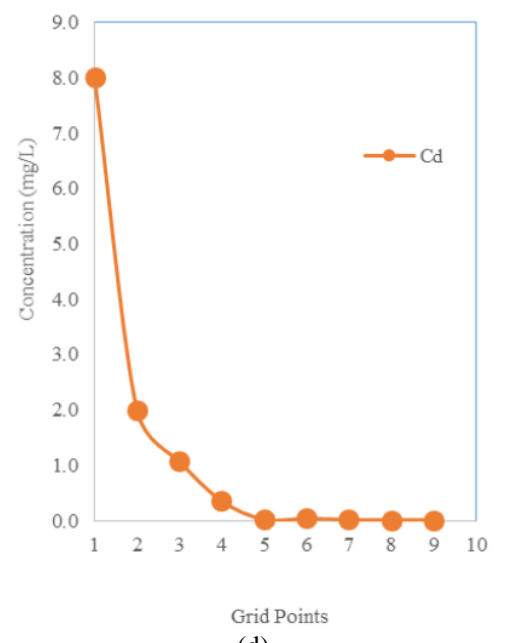

(d)

Fig. 2. Plot of spatial distribution of various metals.

\section{CONCLUSION}

The concentrations of the different metals detected and measured in the samples are presented. It can be concluded that the soils from the landfill sites revealed contaminations by trace and heavy metals. Landfilling is increasingly being recognized globally as an unsustainable approach to handling waste. Other waste processing and treatment initiatives such as waste-to-energy conversion technologies need to be considered by municipalities all over the world.

\section{ACKNOWLEDGMENT}

Financial support from Cape Peninsula University of Technology and City of Cape Town, South Africa for granting access to the various landfill sites.

\section{REFERENCES}

[1] M. Aucott, "The fate of heavy metals in landfills," A Review, New Jersey, Division of Science, Research, Technology, New Jersey Department of Environmental Protection, 2006.

[2] Y. Zhang, D. Yue, and Y. Nie, "Greenhouse gas emissions from two-stage landfilling of municipal solid waste," Atmospheric Environment, vol. 55, pp. 139-143, 2012.

[3] C. R. N. González, E. Björklund, R. Fortez, and V. Cerdà, "Volatile organic compounds in landfill ordorant emissions on the island of Mallorca," International Journal of Environmental Analytical Chemistry, vol. 92 ,no. 12, pp. 1-16, 2012.

[4] J. Pastor and A. J. Hernández, "Heavy metals, salts and organic residues in old solid urban waste landfills and surface waters in their discharge areas: Determinants for restoring their impact," Journal of Environmental Management, vol.95, 2012.

[5] O. M. S. Ismail and R. S. A. Hameed, "Environmental effects of volatile organic compounds on ozone layer," Adv. Appl. Sci. Res., vol. 4, pp. 264-268, 2013.

[6] D. Kulikowska and E. Klimiuk, "The effect of landfill age on municipal leachate composition," Bioresource Technology, vol. 99, pp. 5981-5985, 2008.

[7] S. Mor, K. Ravindra, R. P. Dahiya, and A. Chandra, "Leachate characterization and assessment of groundwater pollution near municipal solid waste landfill site," Environ Monit Assess., vol. 118, pp. 435-456, 2006.

[8] O. O. Ogundiran and T. A. Afolabi, "Assessment of the physicochemical parameters and heavy metals toxicity of leachates from municipal solid waste open dumpsite," Int. J Environ Sci. Technol., vol. 5, pp. 243-250, 2008.

[9] S. Tripathy, P. Bhattacharyya, R. Mohapatra, A. Som, and D. Chowdhury, "Influence of different fractions of heavy metals on microbial ecophysiological indicators and enzyme activities in century old municipal solid waste amended soil," Ecological Engineering, vol. 70 , pp. $25-34,2014$. 
[10] S. Kanmani and R. Gandhimathi, "Assessment of heavy metal contamination in soil due to leachate migration from an open dumping site," Appl. Water Sci., vol. 3, pp. 193-205, 2013.

[11] P. Vandana, N. N. Murthy, J. Environ, and P. S. Sarena, "Assessment of heavy metal contamination in soil around hazaedous waste disposal sites in Hyderabad city (India): Natural and anthropogenic implications," Res. Manage, vol. 2, pp. 27-34, 2001.

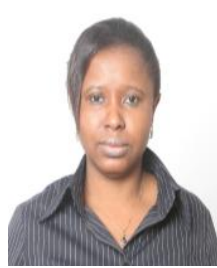

Adelaja Otolorin Osibote completed her undergraduate studies at Ogun State University, Nigeria (now Olabisi Onabanjo University) in physics in 1992 and received her M.Sc. in engineering physics (medical and health physics option) from Obafemi Awolowo University, also in Nigeria in 1999. She obtained her Ph.D (medical physics) from Escola Nacional de Saude Publica (National School of Public Health), Fiocruz, Brazil in 2006. She was a postdoctoral research fellow in the Department of Nuclear Energy, Universidade Federal de Pernambuco (Federal University of Pernambuco), Brazil in 2007 and in the Department of Human Biology (Biomedical Engineering) of University of Cape Town, South Africa in 2008. She was a junior research associate of the Abdus Salam International Center for Theoretical Physics from 2002 to 2006.
Dr. Osibote assumed a faculty position in the Department of Physics, Olabisi Onabanjo University in 1995 and presently in the Department of Mathematics \& Physics, Cape Peninsula University of Technology, South Africa. She has carried out research on several areas including irradiation of foodstuffs, measurement of radioactivity in food and environmental fields, quality assurance in diagnostic radiology and in the developments of algorithms for automated focusing of a microscope for the detection of tuberculosis. She teaches several courses in physics at the University and supervises a number of students.

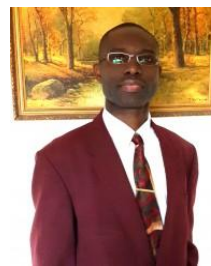

Ademola Rabiu holds a BSc (Hons) and MSc in chemical engineering from Obafemi Awolowo University, Nigeria, BTech in project management and MPhil in commercial law. Ademola is presently a senior lecturer with Cape Peninsula University of Technology, CPUT where he is teaching process design and petroleum production technology. His research interests are sustainable energy, technology which includes thermo-chemical conversion of wastes to fuels; processing of conventional and non-conventional petroleum resources and sustainable resources. 